\title{
A Questão da Mulher e a Aids: novos olhares e novas tecnologias de prevenção
}

\section{The Issue of the Woman and Aids: New Views and New Technologies of Prevention}

Sarita Teresinha Alves Amaro

Doutora em Serviço Social

Coordenadora Regional da Política de DST/AIDS

Secretaria Estadual de Saúde do RS - 13 Coordenadoria de Saúde

Email: saramaroœterra.com.br

\section{Resumo}

A aids cresce em cifras no Brasil e no mundo. No mundo todo, cerca de 42 milhões de pessoas são soropositivas. Desde o início da década de 80 até setembro de 2003, foram notificados 277.154 casos de aids no Brasil. Atrás desses índices está uma triste realidade: a epidemia cresce 9 vezes mais entre as mulheres. São, no geral, jovens ou mulheres casadas ou que têm relacionamento fixo, sem comportamento promíscuo e que contraíram o vírus dentro de "casa". Junto à descoberta da contaminação pelo vírus, vem a dolorosa verdade da traição do parceiro, a implacável confirmação da fragilidade da relação conjugal vivida, mas principalmente, a morte do mito do amor ideal, guardado numa aliança ou numa união estável. Cada vez mais, vidas femininas são ceifadas assim, com essa história de amor incondicional relativo ao parceiro e total ausência de amor próprio. Devoção de um lado e negligência de outro. Mais do que uma suposta questão filosófica, antropológica ou ontológica, creio que, diante dos números apresentados, o baixo auto-cuidado feminino trata-se de um problema de saúde pública. Mas o que temos feito em termos de prevenção a Aids diante do segmento feminino e suas demandas? $\mathrm{Na}$ oportunidade deste relato, teceremos considerações sobre como nós, profissionais de saúde, podemos contribuir na gestão e desenvolvimento de novos programas e tecnologias de prevenção que alcancem o universo feminino e efetivamente desviem-no do comportamento de risco.

Palavras- chave: Aids; Prevenção; Mulher; Saúde; Liberação. 
Abstract

HIV grows in numbers in Brazil and around the world. In the whole world, about 42 millions people are HIV positive. Since the beginning of the 8o's until September of 2003 , there were 277.154 cases of HIV confirmed in Brazil. Behind those rates there is a sad reality: the epidemy grows at a rate 9 times higher among women. They are, in general, youngsters or married women or women with stable relationships, without promiscuous behavior and that acquired the virus inside their "home". Along with the discovery of the contamination caused by the virus, comes the painful truth of the betrayal of the partner, the implacable confirmation of the fragility of the conjugal relationship experienced, but mainly, the death of the ideal love myth, kept in an alliance or in a stable union. Each time more, feminine lives are reaped like this, with this story of unconditional love relative to the partner and total absence of self-esteem. Devotion, on one side and negligence, on another. More than a supposed philosophical, anthropological or ontological issue, I believe that in face of the numbers presented, the low feminine self-care is linked to a of public health problem. In this article, we will weave considerations about how we, health professionals can contribute to the management and development of new programs and prevention technologies that reach the feminine universe and effectively deviate it from the risk behavior.

Keywords: HIV; Prevention; Woman; Health; Liberation.

\section{Introdução}

A democratização dos serviços de saúde e na sua esteira, a cultura de prevenção em saúde, fez escola na década de 8o, enquanto promoção de processos articulados de educação e saúde, lançando uma nova racionalidade no modo de fazer saúde pública e coletiva. Em síntese, durante os anos 8 o reviu-se e recriouse o modelo de atenção à saúde no país, instituiu-se o Sistema Unificado de Saúde e ampliou-se a cobertura assistencial aos cidadãos.

De lá até aqui, temos gradativamente assistido a expansão de uma cultura de prevenção e educação em saúde no país, muitas vezes promovida pela associação da universidade (a partir de suas pesquisas e eventos científicos) e da sociedade (a partir do ativismo de grupos mediante organizações não - governamentais) ao setor público.

Contudo, o baixo ou nulo impacto das atividades de educação e saúde, para além da validade das discussões epistemológicas e científicas que ensejam, têm, no plano prático, caminhado pacientemente ao passo que epidemias como a AIDS avançam a passos largos.

Desde o início da década de 80 até setembro de 2003, foram notificados 277.154 casos de aids no Brasil (Brasil-MS, 2004). Comparativamente, é ainda baixo o percentual de pessoas que adotam o uso consistente de preservativos: $58 \%$ em parcerias eventuais e $11 \%$ em parcerias fixas.

O programa Nacional de DST/Aids, atual Coordenação Nacional de DST/Aids, não tem poupado esforços ao longo dos anos em direção à superação desses índices e redução de vidas perdidas. Atividades formativas junto a profissionais, usuários, professores e alunos têm sido orquestradas.

Contudo, como um estudo que pesquisou o conhecimento de 10.843 escolares de $6^{\mathrm{a}}$ a $8^{\mathrm{a}}$ séries sobre a AIDS em 14 municípios localizados na porção centrooriental do Rio Grande do Sul , a partir de seu acesso a campanhas de prevenção (Menchen ${ }^{1}$, 1994) aponta que o acesso à informação sobre a transmissividade do vírus, bastante comum nas atividades de prevenção, não necessariamente refere educação sexual ou preventiva:

1 MENCHEN, M. B. Sabatina da Aids: trabalho de avaliação da penetração das campanhas educativas de prevenção à AIDS entre adolescentes, alunos da $6^{\mathrm{a}}, 7^{\mathrm{a}}$ e $8^{\mathrm{a}}$ séries do $1^{\circ}$ grau. Santa Cruz do Sul: $13^{\mathrm{a}}$ Delegacia Regional de Saúde, 1994. $38 \mathrm{p}$ 
As questões melhor compreendidas por todos referem o que é mais propalado em todas as campanhas: a transmissão pelo ato sexual e pelo sangue contaminado. Um número não negligenciável de jovens [95,7\%] acredita que haja outras formas de transmissão da doença, (...) como um abraço, e certamente formam fileira com os que tem as atitudes mais discriminatórias em relação aos portadores do vírus ou doentes (....). Ainda em relação a AIDS, tanto adultos (professores) como jovens (escolares) denotam desconhecimento de que o portador pode passar anos com aspecto totalmente saudável, sem mesmo saber que é um portador, que pode infectar terceiros durante esse período, o qual pode estender-se por tempo desconhecido até a manifestação da doença. Enquanto esses aspectos não forem bem compreendidos permanecerá a tendência a não usar preservativo com pessoas de aspecto saudável ou que já são conhecidas a algum tempo. Esses aspectos são algo que merecem ser melhor abordados nas campanhas (Menchen, 1994:5-6).

A pesquisa constata e endossa uma realidade: a perda freqüente da racionalidade para o comportamento de risco e a necessidade de ser urgentemente abordada no cenário social.

Em especial, a questão do comportamento de risco em mulheres chama a atenção, ou seja: o número de mulheres infectadas pelo vírus vem crescendo no Brasil:

Em 1986, contabilizava-se uma mulher infectada a cada 16 homens na mesma situação. Hoje essa razão homem-mulher passou a ordem de 2/1, havendo regiões onde a razão é 1/1. (...) Predominam casos de soropositividade entre jovens (sobretudo na faixa dos 15 aos 19 anos) e mulheres menos escolarizadas (com menos de oito anos de estudo) (Piovesan e Pimentel, 2002, p. 184).

Dados atuais do Ministério da Saúde revelam que a epidemia da AIDS cresce nove vezes mais entre as mulheres:

No Brasil, apenas no ano de 2003, foram notificados 5.762 novos casos da epidemia e, desses, 3.693 foram verificados em homens e $2.069 \mathrm{em}$ mulheres, mostrando que, atualmente, a epidemia cresce mais entre as mulheres. Em $86 \%$ dos casos femininos notificados, o vírus fora contraído mediante relação sexual sem proteção (Brasil-MS, 2003, p.1-20).

São, no geral, mulheres casadas ou que têm par- ceiro fixo e não apresentam "comportamento promíscuo", que contraíram o vírus dentro de "casa" ou de uma relação afetiva estável. Essa realidade se estabeleceu graças à subordinação feminina a um modelo de relacionamento em que o homem governa a relação afetiva e sexual, bem como tudo que a cerca: significados, valores, obrigações e papéis. De fato,

(...) a epidemia do HIV serviu para mais uma vez denunciar as relações de poder que existem entre homens e mulheres, e o dramático impacto dessa assimetria de poder sobre as mulheres (...) em que o sexo não deve ser recusado, sob pena de infringir os modos que aprendemos ser os esperados para o exercício da nossa feminilidade ou masculinidade (....): ter sexo, para os homens e entregar-se sexualmente por amor, para as mulheres (Brasil-MS, 20oo,p.7o).

Relegadas a objeto da relação, muitas mulheres estão submetidas e silenciadas em seu direito de usar preservativo com seu parceiro e assim colocam sua saúde e vida em risco, permanentemente. Junto à descoberta da contaminação pelo vírus, vem a dolorosa verdade da traição do parceiro, a implacável confirmação da fragilidade da relação conjugal vivida, mas principalmente, a morte do mito do amor ideal, guardado numa aliança ou numa união estável. Talvez essa morte simbólica, seja a primeira e mais fatal representação de morte que a AIDS instaura no inconsciente feminino.

Cada vez mais, vidas femininas são perdidas assim, com essa história de amor incondicional relativo ao parceiro e total ausência de amor próprio. Devoção de um lado e negligência de outro. Mais do que uma suposta questão filosófica, antropológica ou ontológica, creio que diante dos números apresentados, o baixo auto-cuidado feminino, trata-se de um problema de saúde pública. 0 cada vez maior investimento em programas de tratamento com antiretrovirais e suprimentos lácteos aos recém nascidos de mães soropositivas, confirma isso.

Mas o que temos feito em termos de prevenção diante do segmento feminino? A primeira resposta imediata a essa pergunta é previsível: temos a camisinha feminina, distribuída nos postos de saúde. Contudo, a questão posta não se resume ao uso da camisinha feminina, mas a antecede. 0 que a mulher conhece de si, do seu corpo, para que possa se enveredar para usar a camisinha feminina? Ou como a mulher interage 
com o corpo do seu parceiro, na relação sexual: ela olha, toca, explora o corpo ou apenas se deixa explorar? E, por fim, está a mulher ativa no exercício de seu auto-cuidado na relação sexual? 0 que sabe e como age a adolescente e a jovem sobre estas questões? E como a escola está agindo social e pedagogicamente na abordagem da educação sexual na perspectiva do gênero feminino?

Estas e outras questões requerem respostas. Além disso, desafiam todos, sociedade, governo e profissionais de diferentes áreas a organizarem ações que capacitem as mulheres para agir na gestão de conflitos e no processo de negociação que a opção por usar camisinha instaura, sobretudo, numa relação estável e durável.

A ênfase à saúde da mulher, para além do uso da camisinha feminina, é importante e urgente. Desconstruir o tabu e aprender a abordar a questão da sexualidade na perspectiva da auto-estima, do autocuidado e do bem-estar, parece ser ao mesmo tempo um compromisso e um desafio. Mas como é possível responder a esse compromisso? Trabalhando o binômio saúde-educação há pelo menos dez anos, temos percebido e defendido a interface e complementariedade dos saberes da área de saúde com os da área da educação como caminho efetivo à construção de uma prevenção de qualidade. É nessa perspectiva, que temos desenvolvido ações de educação e saúde, na forma do que temos chamado de oficinas de saúde e criatividade em DST/AIDS, junto a alunas, alunos, professoras e professores de escolas públicas situadas na região de Santa Cruz do Sul - RS. O processo metodológico desenvolvido passaremos a descrever.

\section{Metodologia}

Fazer prevenção, de um modo geral, é constantemente um desafio. Especialmente, em se tratando de DST/ AIDS, o desafio é redobrado, ao passo que envolve questões culturais e comportamentais, não raro, passadas intergeracionalmente. Operar na desconstrução de tabus e atitudes a ele correlatas, por tudo que representam de anti-pedagógico, faz parte do trabalho educativo a edificar.

Por tudo que implica de mudança em conceitos, valores, sentimentos e atitudes, fazer prevenção em DST/AIDS exige do educador em saúde, não só conhe- cimento do assunto que pretende abordar, mas desenvoltura, habilidade comunicacional, versatilidade e muita criatividade.

Sem esses elementos, corre-se o risco de perder a atenção e o interesse do público focal, acarretando a massiva evasão dos participantes ou, na pior, das hipóteses transformar um assunto que deveria ser cotidiano em algo tão científico quanto incompreensível (ou assombroso), acarretando em sua secundarização.

Para efetuar essa "revolução", as habituais e enfadonhas palestras devem ceder lugar a outras formas de comunicação e ação educativa. Isso requer que se antecipem mudanças importantes nas atitudes do educador em saúde, convertido em facilitador. Assim, a necessária relação horizontal e dialogal entre educador e educando em saúde preventiva, deve vir acompanhada de atividades vibrantes, motivação e incentivo, iniciativa e interlocução ativa. Nesta perspectiva, servem de bússola experiências do Ministério da Saúde (MS) que buscam capacitar profissionais e usuários dos serviços de saúde em várias frentes: da redução de danos à liderança e ativismo na prevenção da epidemia da Aids. Nesses processos, o princípio da inclusão é a tônica: associando pessoas soropositivas a outras negativadas, que precisam saber de sua história de vida, da necessidade de auto-cuidado e do tortuoso processo de luta contra o vírus e o preconceito para aderir e assumir uma postura de prevenção. A estratégia, que tem dado certo para tamanha quebra de tabus e processo educativo, parte:

dos princípios de solidariedade, de tolerância, de convivência e complementaridade de conhecimentos e apoio emocional entre participantes e facilitadores (...) e atua por meio de exercícios, jogos e histórias de vida mediante grupos onde pessoas soropositivas refletem sobre suas vidas e seu papel político diante da epidemia face a comunidade onde estão inseridas (Brasil-MS, 2000:17)

Tais experiências têm se revelado luzes e, segundo as mesmas, temos organizado oficinas de prevenção no meio escolar em que, no geral, mulheres, na pele de adolescentes, jovens ou adultas, estudantes e professoras, são partícipes. Nessas oficinas, temas como prazer, auto-conhecimento e a prática do auto-cuidado como forma de amor próprio, são a tônica.

Mas por que a escola? - pode-se questionar. Acreditamos, acompanhando a posição de profissionais da 
saúde atuantes no MS e autores como Arruda e Cava$\sin (2000)$ que a escola é um espaço privilegiado à promoção e desenvolvimento de ações sociais, culturais e de saúde que direta ou indiretamente defendam a valorização da vida, da saúde e de relações humanas mais respeitosas. Essa visão tem sido fortalecida, sobretudo, a partir da nova Lei de Diretrizes e Bases, de 1996, mediante a qual, as escolas tornaram-se abertamente protagonistas de um processo com o qual sempre guardaram estreita relação: o fortalecimento da cidadania. Com os “ (...) parâmetros curriculares nacionais, elaborados pelo Ministério da Educação (...), partiu-se à implantação dos conteúdos de sexualidade e saúde reprodutiva, (...) ética, orientação sexual (...), os quais devem ser tratados de forma transversal, isto é, poderão ser abordados em qualquer momento e por todas as disciplinas" (Arruda e Cavasin, 2000: 14).

Realizar orientação sexual, na perspectiva de gênero, contudo, não é fácil. Se no geral, as atividades de prevenção convencionais, na forma de palestras e distribuição massiva de cartazes, folders e camisinhas, pouco impactam na modificação de condutas e auto-cuidado, quando se trata do segmento feminino, historicamente alijado desse foco pelo tabu que ainda impera, há muito o que se recriar para mobilizar sua atenção e adesão.

A metodologia que melhores resultados têm apresentado, e pela qual nos guiamos, segue a linha problematizadora-construtivista, vinculada ao pensamento de Paulo Freire, em que a leitura e tomada de posição no mundo, atravessa obrigatoriamente a realidade cotidiana das interações e vivências de cada sujeito nesse mundo. Nesse sentido, o conhecimento é uma construção da pessoa, no caso do aluno, em diálogo e interação com as construções de outros sujeitos com quem convive (os professores, pais, colegas, amigos, namorados,....).

Assim, importa trazer à luz que interações são essas, como elas se organizam e definem nossa conduta - de modo mais ou menos autônomo, ou mais ou menos inseguro - problematizando e refletindo sobre as conseqüências concretas de cada atitude tomada ou negligenciada. Arruda e Cavasin (200o) recomendam que as estratégias pedagógicas, dentro dessa metodologia, devem ser lúdicas e criativas, para facilitar a participação do aluno, criar o interesse grupal e possibilitar um clima de confiança que permita que o aluno aceite e viva o processo de conhecimento sobre o assunto. As mesmas autoras indicam ao profissionais que usam tal metodologia que optem por dinâmicas de grupo, oficinas, jogos educativos, estudos de casos, dramatizações e atividades similares, dado que produzem melhor resultado.

Outro autor, Ezequiel Ander-Egg (1987), também defende o uso de estratégias assim guiadas. $\mathrm{O}$ autor, conhecido pela metodologia da animação sócio-cultural, refere que a via lúdico-criativa aciona tanto o interesse das pessoas - representando uma estratégia de aproximação e facilitação do processo educativo como o favorece o caminho da prestação de esclarecimentos, superação de medos, mitos, posturas discriminatórias e contribuir à reversão de situações e comportamentos de risco. Nesse sentido, recomenda o emprego de oficinas e atividades interativas, dinâmicas, instigantes, curiosas, que podem usar desde a exibição de vídeos, expedições ou visitas até atividades cênicas, recreativas, desportivas e/ou artístico culturais como recursos a serviço da prevenção.

Amaro (2004), quando pensa prevenção em saúde, sugere que a mesma adote protagonismo juvenil associado a uma forma positiva de sensibilização:

Em lugar do aterrorizamento, o esclarecimento. Em lugar de ameaçar, educar e ensinar. Em lugar de informar, numa perspectiva transmissiva; formar, na perspectiva de "promover sua reflexão". Em lugar de dirigir e comandar mudanças de comportamento; orientar decisões autônomas e conscientes. Em lugar "falar", desenhar, brincar. Em lugar focalizar em mensagens que falam do que "se perde", demonstrar isso, fazendo sentir o que se pode ganhar (Amaro, 2004: 6).

Mas para adotar essa proposta metodológica, é preciso que educadores reúnam certas e indispensáveis atitudes. Inicialmente, importa considerar que o tema sexualidade deve ser tratado com respeito e ao mesmo tempo sem preconceito. Certamente, isso não é fácil. O oficineiro, investido na condição de educador, no geral, não nutre preconceitos sobre o tema. Mas, pode acontecer que, mesmo contrário a sua pretensão aja desrespeitosamente. Aspectos sutis da comunicação oral ou gestual, podem reproduzir, expressões e mitos cercados de farpas morais. Os apelidos associados a pênis e vagina, portanto, devem ser abandonados - salvo, quando os participantes os mencionem. Piadas e representações gráficas distorcidas 
ou assombradoras também acabam gerando efeito contrário, pouco ou nada acrescentando de conteúdo pedagógico. Perguntas devem ser respondidas sem ironizações, investindo no diálogo e reflexão dos participantes. Partir das experiências concretas, mediante comentários, relatos e perguntas dos alunos, é além de válido, bastante importante a sua problematização; contribuindo no desmantelamento de mitos e engodos que vão se cristalizando em torno da questão.

Arruda e Cavasin sugerem, sinteticamente, como postura profissional:

informar as alunas e os alunos corretamente sobre o que se sabe sobre o tema em questão, tendo sempre a ciência como aliada; criar um clima favorável para que os alunos possam colocar suas dúvidas sem constrangimentos; esclarecer essas dúvidas; incentivar os jovens a falar sobre o que pensam e sentem, sem se exporem; desmitificar crenças, tabus e preconceitos que existem sobre os diferentes aspectos da sexualidade; provocar uma reflexão crítica sobre os valores de nossa sociedade, especialmente sobre as relações hierárquicas de gênero; despertar a necessidade de se estabelecer relações igualitárias entre as pessoas (Arruda e Cavasin, 20oo: 19).

Agir desse modo é um importante ponto de partida para revelar-se um facilitador do processo de conhecimento e muitas vezes de auto-descoberta dos alunos com relação ao tema sexualidade e sua importância na valorização da vida e saúde.

\section{A Tecnologia em Ação}

Na condição de responsáveis pela Política de DST/ AIDS na $13^{\text {a }}$ Coordenadoria Regional de Saúde, situada Santa Cruz do Sul - RS, é comum recebermos e atendermos demandas de escolas relativas à solicitação de material de apoio (cartazes, vídeos, preservativos e folders), sobretudo na proximidade de dezembro, alusivo ao Dia Mundial de Combate a AIDS. Quando essas demandas começaram a ficar regulares, decidimos conversar com as professoras interessadas e/ou diretoras das escolas para avaliar se apenas o repasse desse material seria válido. A partir desses contatos, percebeu-se que não havia da parte das direções visão de outra forma de abordar a questão da prevenção da AIDS entre os estudantes, para além da exibição de vídeo ou distribuição de folders e preservati- vos. Apresentamos, a título de sugestão, que uma alternativa de qualidade seria a realização de oficinas pelas professoras. A idéia foi bem recebida mas em termos práticos, as direções deixaram claro que de um modo geral as professoras não dispunham de formação para realizar tal proposta. Foi assim que passamos a realizar oficinas de educação e saúde nas escolas abrangidas pela regional e cuja experiência passaremos a relatar na seqüência.

Conduzidas por nós mesmas, dentro de uma proposta participativa, construtiva e problematizadora, organizamos a agenda de oficinas em diferentes escolas e turmas. A idéia era partir das dúvidas e interesses manifestos pelos estudantes e ir descortinando suas descobertas e esclarecimentos sobre o tema sexualidade, auto-cuidado e prevenção de DSTs e AIDS. Partindo do entendimento de que a sexualidade não é expressão de um instinto, e sim a expressão de um desejo de prazer, fomos traduzido nossas oficinas como lúdico-criativas, ao passo que utilizavam jogos, filmes, artes cênicas e música como caminho à promoção da saúde e prevenção de DST/AIDS.

Reconhecendo que crianças e adolescentes de diferentes idades, no geral, apreciam atividades desportivas e competições e empregando essa condição em favor da educação para saúde sexual, temos proposto jogos e atividades desportivas que os convidem a observar e pensar as diferenças anatômicas dos corpos femininos e masculinos. Num dos jogos que desenvolvemos, definido um tempo cronometrado, meninos e meninas separados em equipes, são orientados tomar de uma caixa repleta de vestimentas diversas, peças de vestuário contrárias ao seu gênero, devendo vesti-las (sobre suas próprias roupas) o mais rápido possível. Em meio a risos, a atividade serve à iniciação do conhecimento das diferenças físicas, principalmente se acompanhadas de um debate orientado, que indague para além da superficialidade das peças do vestuário. Questionar porque os meninos não precisaram usar sutiã ou tiveram dificuldade de colocar a meia-calça, pode catalisar uma reflexão preparatória a outros aprofundamentos relativos à sexualidade.

Assim como os jogos, independentemente da idade, uma boa estratégia tem sido reunir a arte dramática ao objetivo de prevenção. A montagem de representações teatrais e cenários (quarto, cinema, wiskeria, o postinho de saúde, o brete,...), dentro do espaço 
escolar, tem capturado positivamente as atenções e interesses dos estudantes e professores participantes. Colabora o fato do teatro e seu cenário dialogar com o campo do imaginário coletivo, atraindo atenções ao associar o conteúdo sexualidade (bastante imagético) à forma estratégica, criativa e artística das artes cênicas.

Em certa escola estadual, realizamos uma oficina chamada Mundo da Fantasia, em que as pessoas para entrar tinham que tirar os calçados ou alguma peça a sua escolha, que portassem para "pagar a entrada". As coisas eram guardadas por uma oficineira que ficava à porta e dava uma "senha secreta", (um texto escrito num papelzinho), para cada um. Só podiam entrar em média 15 participantes de cada vez. As senhas continham geralmente frases como: "transar sem camisinha não dá nada", "ele disse que me ama e não me trai, por isso eu transo com ele sem camisinha", "que garota lindinha e limpinha, essa não tem AIDS", ou ainda, "transar com mulher casada, isso é que é sexo seguro". Essas frases eram entregues num papelzinho, o qual cada um deve abrir e ler para si, ao entrar e sentar na sala. Cadeiras dispostas em um círculo, após a apresentação da oficineira, os participantes iam sendo orientados sobre a atividade. A oficineira perguntava primeiro quem se considerava esperto? Raramente alguém se manifestava diante da primeira indagação. Mas, após algumas insistências, sempre alguém se indicava ou era indicado. Esse momento era importante para se identificar as lideranças e sua relação com o tema. Pedia-se a cada um que novamente de uma olhadinha na sua senha. Seguiam-se as regras da atividade: todos nós estaremos brincando de verdade e mentira. Pergunta-se a cada um, um de cada vez, se a sua senha revela uma verdade ou uma mentira, pedindo que ainda não revele a frase, apenas comente. Os comentários vêm com explicações breves como "é mentira, se fizer isso tá ralado, tá morto" ou "concordo, é verdade". Depois da pessoa manifestar sua opinião pedia-se a ela para ler a frase e coloque a opinião da pessoa em discussão. Os líderes eram os primeiros a pedir para falar, e no geral, sua opinião, quando não era seguida, pelo menos confundia os demais, desviando-os da sua percepção. A atividade seguia, as discussões se acalorando, depoimentos, exemplos, perguntas e respostas acontecendo (com a participação ativa do oficineiro nos esclarecimentos) e no final a oficineira pergunta: qual é o nome do jogo? A resposta certa nunca vem imediatamente. Sempre precisa de um tempo. Um fala uma coisa e respondo que "não" ou "quase", até que alguém liga as peças do mosaico e decifra o nome do jogo: mundo da fantasia. O mais importante é levar o grupo a bater-papo, num clima de desafio e expectativa. No final, quando se decifra o nome do jogo, a oficineira reflete sobre a experiência ali vivida: "Para alcançar a verdade, precisamos refletir juntos, para vencer o enigma também. $\varepsilon$ assim com o vírus da AIDS. As pessoas precisam esclarecer umas às outras senão não funciona. Uma pessoa esclarecida é sempre bom, mas é pouco na luta contra a AIDS, pois se ela fraquejar, pode pegar o vírus”. Essas falas associadas ao contexto vivido são mais significativas do que discursos lidos ou falados durante horas, em palestras.

Noutra escola, montamos uma super oficina de DST/AIDS, em meio as atividades de uma Feira de Saúde. As outras "bancas" utilizavam o pátio. Pedimos à diretora que reservasse uma sala de aula, tv, vídeo, e algumas peças (cortinas, toalhas de mesa, almofadas, geralmente existentes nas classes iniciais). Com esse material, mais uma fita de vídeo selecionada e muitos folders, cartilhas, cartazes e camisinhas (masculinas e femininas) fomos à campo. Os cenários montados: 1. uma wiskeria (com espelhos, cama, luzes pisca-pisca e bandejas contendo "canapés" ou drinks de preservativo masculino), 2. um miniauditório onde se assistia a um filme sobre saúde sexual e 3. Uma sala de bate-papo onde a gente conversava sobre o que aprendeu. Cada grupo de 15 era encaminhado a entrar primeiro na wiskeria e ficar à vontade, sentado, deitado ou em pé. As pessoas entravam "de cabeça" na representação. Nesse cenário, a oficineira orientava como agir ali. Aceitar um "canapé" ou drink de camisinha era obrigatório. Depois precisávamos medir o nível de "tesão". Nessas horas, as pessoas riem muito e ao mesmo tempo ficam um pouco temerosas. È mostrado, o tesômetro (um borbulhador em vidro e com líquido colorido, que responde à temperatura do corpo). Começa a brincadeira mais esperada da oficina: se o líquido subir e borbulhar o sujeito é "nota dez em tesão". Caso contrário, atribuem-se valores correlatos ao nível obtido: 5, 7, 9. Todos participam, opinam e riem muito (tudo no maior respeito, sem ser invasivos ou indelicados). Pedem para a mãe ou a professora também usarem o tesômetro. Pedem para "usar" de 
novo, pra confirmar o "diagnóstico". Todos entendem que é uma brincadeira, mas como não sabem como funciona o aparelho ficam curiosos e alvoroçados. Uns dizem que está errado, que são mais "tesudos" que o outro que levou o líquido ao topo. A oficineira propõe a reflexão, nessa oportunidade, sobre os mitos de sexualidade, relativos à imagem que passamos. E esclarece que o mais importante é reconhecer-se que todos têm muita saúde sexual e essa "saúde" toda deve ser preservada, conservada, cuidada. Por isso os drinks e canapés de camisinhas são tão necessários. Mostrase a camisinha masculina, entregue gratuitamente nos postos de saúde do SUS. Tira-se da embalagem, distribui-se outras para que cada um acompanhe a oficineira e faça o mesmo. Fala-se da lubrificação necessária, dos cuidados que se deve ter ao guardar em local seco e ventilado, dos diferentes tamanhos, como se coloca, quem pode colocar, se dói, vantagens e desvantagens. No jogo de perguntas, respostas e relatos, vai se desenvolvendo a conversa preventiva. Esgotado o assunto da camisinha masculina - tendo preliminarmente, combinado com algum oficineiro ajudante ou mesmo uma professora que pergunte "e se o parceiro não quer usar camisinha como a mulher faz?" - surge a oportunidade de apresentar a camisinha feminina a todas e todos. Mostra-se a camisinha, ainda na embalagem fechada e vamos abrindo e explicando como se coloca, quanto tempo antes, os vantagens e desvantagens. Fala-se de relacionamento de homens com homens, mulheres com mulheres e da relação heteross exual, sobre a escolha do preservativo mais adequado a cada caso e necessidade (tamanhos, com ou sem espermicida, com ou sem sabor,...). Tudo isso ocorre apenas no cenário da wiskeria, no interior da sala de aula. Na seqüência, os convidados (da wiskeria) são orientados a seguir para o outro cenário: o miniauditório. Neste, a tv e o vídeo são os principais recursos. $\mathrm{O}$ vídeo apresentado trata das diferenças anatômicas entre homem e mulher, com ênfase nos genitais. Não raro, sem a malícia habitual, é a primeira vez que muitas meninas e meninos vêem o corpo do "outro" de um modo tão claro e compreensível. Falase de ereção e de menstruação, esclarecendo como esses fenômenos ocorrem. Nesse cenário, no geral, não há risos, ao contrário, o público fica bastante atento. Tão logo o filme termina, um breve momento de reflexões ocorre, mas não é obrigatório, já que o terceiro cenário é o espaço para o bate -papo sobre tudo o que se viu e se pensou nas últimas horas. Nesse cenário, situado ao fundo da sala de aula, estão afixados cartazes e exibidos folders e cartilhas informativas sobre DST/AIDS. O momento é mais guiado pelo público, que pode comentar o que já aprendeu e o modo como está vendo a sexualidade e a prevenção de DST/AIDS, a partir da oficina. 0 espaço também serve como tiradúvidas: pode-se colocar camisinha na carteira? Transar anal não precisa de camisinha? Mulher não passa aids, por que não tem esperma? As respostas negativas a todas essas são seguidas de esclarecimentos da oficineira e pedidos de colaboração aos presentes -

Vocês concordam? O que vocês acham? É assim mesmo ou diferente? Vocês já ouviram isso de alguém?. Resultado: todos crescem, oficineiros e participantes. Algumas variações na metodologia podem ser feitas, no ordenamento dos cenários,por exemplo. Colocar o filme antes da wiskeria é recomendável. No geral, a atividade requer entre 1 h3o e $2 \mathrm{~h}$ de duração.

O jogo, o teatro e todos os recursos usados, ensejam que se abordem as demandas do grupo, em torno de temas como: conhecimento do corpo, virgindade, fertilidade, planejamento familiar, orgasmo feminino,ejaculação precoce, ponto "G", sexo anal, oral e vaginal, homossexualidade, etc. Da mesma forma, oportuniza que se fale diretamente sobre decisões $e$ atitudes como: quando, com quem e, principalmente, como transar, com base no diálogo entre os parceiros e sempre usando camisinha.

\section{Resultados}

Num primeiro olhar, no horizonte dos resultados, avaliamos que a execução das oficinas tal como apresentamos, representaram tanto esclarecimento sobre as DST/AIDS e caminhos a sua prevenção, como o aprofundamento do conhecimento da subjetividade de cada sujeito: heterossexual ou homossexual, homem ou mulher, casado ou solteiro, adolescente ou adulto, religioso ou ateu.

Visto que as atividades realizadas não se resumiram a uma proposta transmissiva de conhecimento, mas numa troca, entre oficineiro e público, pode-se dizer que o clima amistoso e agradável implicou resposta atitudinal favorável diante do tema, representando não só uma compreensão do grave quadro epide- 
miológico em que estamos, como a aceitação da mudança comportamental a adotar.

As pessoas com quem interagimos, conversamos e falamos de saúde e prevenção parecem ter entendido bem a idéia de que o auto-cuidado é uma forma de amar ao outro e a si mesmo, bem como que falar abertamente sobre o assunto (usar camisinha,por exemplo) é uma demonstração de maturidade e responsabilidade.

Ver desfilar indagações e comentários em meio as oficinas, inicialmente cercados de mitos e preconceitos, serem descontruídos e recompostos numa referência mais consciente e responsável corresponde, como diria Marx, a "ouvir a relva crescer". "Ouvir" a queda dos medos e tabus e o fortalecimento da atitude consciente relativa a sexo seguro entre os participantes das oficinas são sinais de uma mudança de atitude contagiante que estamos conquistando. São sinais de resultados.

Sabemos que a luta contra o vírus da AIDS não é fácil e requer amplas e muitas medidas articuladas. Mas no que se refere às oficinas, o sucesso de público, a solicitação constante das escolas "pedindo" mais vezes aquela oficina divertida que dura meses na conversa da garotada, é um sinal de que estamos no caminho certo.

Os resultados, assim, são contados em atitudes curtas, ordenadas ou não, mas que têm na crença na vida sua maior potencialidade. Acreditamos, que a cada homem, mulher, mãe e pai, filho ou filha que trouxemos para o lado "de cá", do sexo seguro, com camisinha, do diálogo, do respeito à individualidade e da preservação da vida, estamos totalizando uma vitória, nessa guerra de grandes perdas.

Cada um, nessa matemática anti-aids às vezes conta "quatro", "dez" e até "duzentos". Tudo depende da rede de relações envolvida, acionada. As oficinas instigam as mulheres a falarem com seus parceiros sobre seu comportamento sexual, colocando a camisinha em discussão. As mães, encorajam-se a falar sobre as DST e a epidemia da AIDS com seus filhos e filhas e com os amigos e colegas de seus filhos. Os professores que, a partir da oficina, aproveitam suas aulas para fazer sua parte na prevenção à aids, por sua vez, atingem um grande grupo de pessoas: ao falar ao aluno, alcançamos sua namorada, a melhor amiga dela, a mãe da melhor amiga, seu companheiro, e assim sucessivamente.
Nessa rede, por meio dos conhecimentos e depoimentos trocados, as pessoas partícipes nas oficinas refletiram - e como multiplicadores têm desencadeado a reflexão - não apenas sobre o papel de cada um na erradicação da AIDS, mas, principalmente, sobre o que têm priorizado e como têm orientado sua vida e daqueles que amam.

\section{Discussão e Conclusões}

Mulheres, convertidas em divas ninfomaníacas ou vocacionadas freiras são cada vez mais mitos, na contemporaneidade. As escravas do sexo, de fato, não são mulheres que ganham a vida fazendo sexo, mas que o fazem por obrigação, trabalho, medo, opressão ou rotina conjugal e não por prazer. 0 pecado da luxúria, certamente não é o seu mal. Da mesma forma, as religiosas em seu fervor e devoção, guardam em seu passado dores e dramas de mulheres comuns, que amam, odeiam, temem, gritam ou silenciam suas amarras, marcas e algozes. 0 pecado da devoção talvez seja o seu mal.

Enquanto alimentamos esses dois mitos nos modelos e exemplos que oferecemos a nossas meninas e adolescentes, estamos literalmente "fabricando" mulheres para obedecer, devota e cegamente a um homem: o pai, o irmão, o namorado, o esposo, o amante. Sua cegueira, revelada na contração do vírus, decorre desse sentimento de subordinação à devoção, secularmente imposto ao gênero feminino.

Quando falamos nas oficinas às mulheres, na pele de alunas e professoras, estamos realmente "falando" às meninas, mulheres, mães e gerações de mulheres que as mesmas representam e estão por formar. Precisamos falar com "todas" essas mulheres ao mesmo tempo e no diminuto, escasso e efêmero tempo que nos emprestam. Precisamos falar à criança e à avó, bem como à mãe e à tia, ao mesmo tempo. A escola tem se revelado potencial para esse feito. A saúde na escola é o caminho mais curto para esse diálogo intergeracional e ontológico. É uma revolução, sem dúvida.

Mas para ensinar as mulheres a dança da auto-estima e do seu empoderamento, é preciso que se tenha testemunhos. Palestras com mulheres que ganham e que perdem nesse "jogo de damas" são importantes. 0 depoimento de mulheres que amaram demais e contraíram o vírus, alerta as mulheres com relacionamen- 
to fixo a lutarem por sua vida e por seus filhos, zelando por sua força vital para protegê-los e criá-los, dando-lhes a vida, como a natureza feminina ordena e não o contrário.

Da mesma forma, o exemplo de mulheres que "ganharam" ao amarem demais "a si mesmas" e, apesar das dificuldades e instabilidades na relação conjugal, conseguiram cultivar o uso do preservativo, demonstra o cotidiano possível da luta contra a AIDS na negociação conjugal sobre a parte mais íntima da vida a dois que é o sexo.

Esses testemunhos ventilam idéias, convicções e maneiras diversas da mulher tomar uma decisão e posição consoante com o que pretende fazer com seu tempo presente e futuro. Decidir o que quer ser antes da vida profissional e do estado civil, na vida pessoal e existencial, depende dessa visão prospectiva. Orientar a mulher a agir nesse caminho decisório requer uma ênfase no respeito a princípios como auto-cuidado, auto-estima, dignidade e individualidade. Ao lado destes, demanda que se processe um rompimento com culturas machistas, submissoras e opressoras da mulher e de suas necessidades individuais. E não há um X-Men que realizará esse feito. É a mulher, propriamente, a autora de seu empoderamento.

Como acreditamos que o empoderamento é um processo tanto racional como emocional, entendemos que quando a prevenção emprega esses dois domínios e aciona na mulher dúvidas e respostas comportamentais e afetivas, o trabalho preventivo está em pleno "funcionamento" e ruma ao êxito. É preciso considerar que apesar de ser importante focalizar na difusão de informações (sobre segurança, saúde genital, prazer sensual, escolha racional de parceiros), com vistas a preservação da soronegatividade, isso não é o suficiente para a mulher. O suficiente, no universo feminino, é reunir esse equilibrio biológico-imunológico relativo à saúde e segurança ao equilíbrio afetivo, relativo à qualidade da relação amorosa e/ou conjugal em que se insere o ato sexual.

A prevenção só perde para o vírus da AIDS, quando o profissional não sabe conjugar esses dois domínios, a segurança e a afetividade. Tudo porque, lá no fundo, o imaginário feminino, clama por atenção, carinho e duração. Para ter esse conjunto de condições, a mulher corre riscos, todos os riscos. Contra a prevenção e em favor da AIDS, somam-se os medos da perda do status de companheira ou esposa, ou mesmo de amante fixa, como muitas mulheres vivem. 0 medo da solidão e do envelhecimento é tão fatal quanto qualquer outro método mortal, dado que faz a mulher negligenciar a si mesma, em nome do suposto amor ou sonho romântico.

É preciso ser dito às mulheres que não há beleza ou romantismo algum em morrer por amor ou por excesso de confiança. Também não há problema algum, ao contrário, em explorar o corpo de seu parceiro, brincar com ele e obter o máximo de prazer com o máximo de segurança. Isso deve ser não apenas dito, mas ensinado às mulheres nas campanhas pré-nupciais, na aula de biologia e sexualidade da escola, na palestra sobre saúde do(a) trabalhador(a) na empresa.

Para ganhar o jogo contra a aids, a prevenção precisa investir na capacitação de profissionais de saúde e em ações de saúde afinadas com esse quadro de necessidades e sensibilidades. É preciso que se fale à mulher mensagens como "aprenda a segurar seu parceiro usando camisinha". Precisamos de cartilhas sobre isso. Cartilhas educativas que mostrem em frases, diálogos e posições, como fazer, a exemplo do Kamasutra, de modo interessante e confiável. Precisamos de concursos de crônicas - lançados pelo MS em que pessoas reais, contam suas experiências sexuais com preservativo. A divulgação e publicação das crônicas, certamente servirá à profusão de imagens eróticas e significados afetivos associados à relação sexual com camisinha, promovendo o método seguro, subliminarmente. Precisamos de miniaturas de bonecas e bonecos promocionais, que ensinem, brincando, crianças a partir de 7 ou 8 anos de idade a usar camisinha, a exemplo do modo como outras gerações brincavam com as roupas e acessórios dos bonecos Ken e Barbie. Essas peças, poderiam ser produzidas pelo Estado com o apoio de empresas socialmente responsáveis, a serviço exclusivo da prevenção de DST/ AIDS nas classes iniciais das escolas.

O que não podemos é restringir nossa visão e ação a um elenco de métodos de prevenção que se resumem a palestras, folders e vídeos centrados em discursos, parábolas, imagens horrendas de como se "morre" doente de aids, ou conselhos do tipo "não faça agora o que eu fiz ontem, por que eu estava errado". Isso nem sempre funciona e, antes assombra do que educa o interlocutor, afastando sua atenção do assunto em tela. 
No horizonte dessas ações estratégicas está a promoção de uma nova liberação feminina, desta vez voltada a saúde sexual e à preservação da vida. É urgente que a mulher, formadora de opinião, chefe de família, mãe e professora, esteja no centro das atenções na prevenção das DST e, sobretudo, da AIDS. Fazendo isso estaremos fazendo muito. Estado, profissionais de saúde e ONGs temos esse desafio pela frente. As estatísticas, gradualmente mais baixas de novos casos soropositivos femininos é o game-off da prevenção contra a AIDS.

\section{Referências}

AMARO, S. Memória do projeto rede social Cara Limpa: criatividade, teatro e histórias em quadrinhos na luta contra as drogas. Porto Alegre: AGE, 2004. 36 p.

ANDER-EGG, E. Perfil del animador socio-cultural. San Isidro: Humanitas, 1987. $117 \mathrm{p}$.

ARRUDA, S., CAVASIN, S. Escola, orientação sexual e programas preventivos. In: BRASIL. Ministério da Saúde. Secretaria de Políticas de Saúde. Coordenação Nacional de DST e Aids. Prevenir é sempre melhor: 99. Brasília, 200o. p. 14-24.
BRASIL. Ministério da Saúde. Coordenação Nacional de DST e AIDS. Ativismo e liderança: uma metodologia na luta contra a Aids. Brasília, 200o. $76 \mathrm{p}$

BRASIL. Ministério da Saúde. Coordenação Nacional de DST e Aids. O perfil das DST/AIDS no Brasil e metas de governo para o controle. Brasília, 2003. $20 \mathrm{p}$

BRASIL. Ministério da Saúde. Dados em DST e Aids. Disponível em: <http://www.aids.gov.br >. Acesso em: 10 fev. 2004.

MENCHEN, M. B. Sabatina da Aids: trabalho de avaliação da penetração das campanhas educativas de prevenção à AIDS entre adolescentes, alunos da $6^{\mathrm{a}}$, $7^{\mathrm{a}}$ e $8^{\mathrm{a}}$ séries do $1^{0}$ grau. Santa Cruz do Sul: $13^{\mathrm{a}}$ Delegacia Regional de Saúde, 1994. $38 \mathrm{p}$

PIOVESAN, F; PIMENTEL, S. (Coord.). Relatório nacional brasileiro: convenção sobre a eliminação de todas as formas de discriminação contra a mulher - CEDAW - protocolo facultativo. Brasília: Ministério das Relações Exteriores, 2002. 248 p. 